Article

\title{
Gas Chromatography-Mass Spectrometry Analysis of Compounds Emitted by Pepper Yellow Leaf Curl Virus-Infected Chili Plants: A Preliminary Study
}

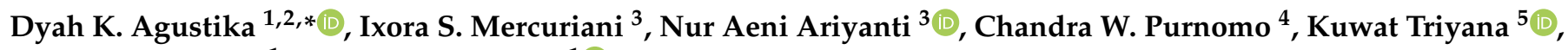 \\ Daciana D. Iliescu ${ }^{1}$ and Mark S. Leeson ${ }^{1}$ (D) \\ 1 School of Engineering, University of Warwick, Coventry CV4 7AL, UK; D.D.Iliescu@warwick.ac.uk (D.D.I.); \\ Mark.Leeson@warwick.ac.uk (M.S.L.) \\ 2 Department of Physics Education, Universitas Negeri Yogyakarta, Yogyakarta 55281, Indonesia \\ 3 Department of Biology Education, Universitas Negeri Yogyakarta, Yogyakarta 55281, Indonesia; \\ ixomerc@uny.ac.id (I.S.M.); nuraeni@uny.ac.id (N.A.A.) \\ 4 Department of Chemical Engineering, Universitas Gadjah Mada, Yogyakarta 55281, Indonesia; \\ chandra.purnomo@ugm.ac.id \\ 5 Department of Physics, Universitas Gadjah Mada, Yogyakarta 55281, Indonesia; triyana@ugm.ac.id \\ check for \\ updates \\ * Correspondence: Dyah.Agustika@warwick.ac.uk
}

Citation: Agustika, D.K.;

Mercuriani, I.S.; Ariyanti, N.A.;

Purnomo, C.W.; Triyana, K.; Iliescu,

D.D.; Leeson, M.S. Gas

Chromatography-Mass Spectrometry Analysis of Compounds Emitted by

Pepper Yellow Leaf Curl

Virus-Infected Chili Plants: A

Preliminary Study. Separations 2021, 8 ,

136. https://doi.org/10.3390/

separations 8090136

Academic Editors: Miguel

Ángel Rodríguez-Delgado,

Bárbara Socas-Rodríguez and

Alena Kubatova

Received: 24 July 2021

Accepted: 25 August 2021

Published: 27 August 2021

Publisher's Note: MDPI stays neutral with regard to jurisdictional claims in published maps and institutional affiliations.

Copyright: (c) 2021 by the authors. Licensee MDPI, Basel, Switzerland. This article is an open access article distributed under the terms and conditions of the Creative Commons Attribution (CC BY) license (https:/ / creativecommons.org/licenses/by/ $4.0 /)$.

\begin{abstract}
Pepper yellow leaf curl virus (PYLCV) is a threat to chili plants and can significantly reduce yields. This study aimed as a pilot project to detect PYLCV by analyzing compounds emitted by chili plants using gas chromatography-mass spectrometry (GC-MS). The samples investigated in this research were PYLCV-infected and PYLCV-undetected chili plants taken from commercial chili fields. The infection status was validated by using a polymerase chain reaction (PCR) test. A headspace technique was used to extract the volatile organic compounds emitted by plants. The analysis of GC-MS results began with pre-processing, analyzing sample compound variability with a boxplot analysis, and sample classification by using a multivariate technique. Unsupervised multivariate technique principal component analysis (PCA) was performed to discover whether GC-MS could identify PYLCV-infected or not. The results showed that PYLCV-infected and PYLCV-undetected chili plants could be differentiated, with a total percent variance of the first three principal components reaching 91.32\%, and successfully discriminated between PYLCV-infected and PYLCV-undetected chili plants. However, more comprehensive studies are needed to find the potential biomarkers of the infected plants.
\end{abstract}

Keywords: pepper yellow leaf curl virus; plant disease detection; gas chromatography-mass spectrometry; multivariate analysis technique

\section{Introduction}

Chili (Capsicum annum L.) contains high levels of vitamins and minerals, which are very beneficial for human health. Besides being consumed as a seasoning, chilies are also used for food dye and are essential ingredients for the pharmaceutical and cosmetic industries [1,2]. Due to their incredible benefits, the consumption of chilies in Indonesia has increased by almost $29 \%$ over the period of 2013-2018. Furthermore, the plant's influence on the national economic dynamics is significant since it is included as one of the largest contributors to inflation. Indonesia itself has the second largest chili harvest area globally and the fourth largest chili production, with a contribution of $5.89 \%$ to the total world chili production [3].

In 2018, the productivity of chilies in Indonesia experienced a considerable decline (some 11.06\%) [3]. One of the causes of this decrease was the presence of various diseases caused by viruses. Pepper yellow leaf curl virus (PYLCV), which belongs to the genus of Begomovirus [4,5], is the main virus that attacks chili plants, and in 2019 the virus attacks 
reached 19\% of the total area of Indonesian chili plantations [6]. PYLCV causes yellow mosaics, the leaves to shrink and curl up or down, and the plant to become stunted [7,8]. This virus can also cause the inhibition of fruit formation and abnormal development, resulting in a plant of no commercial value [9]. PYLCVs are transmitted by the insect vector Bemisia tabaci $[10,11]$. The rate of loss caused by PYLCV in commercial chili production is in the range of $20 \%$ to $100 \%$ [7,12].

Techniques used to detect virus-infected plants have commonly been based on deoxyribonucleic acid (DNA), such as polymerase chain reaction (PCR) testing [13-16]. This method provides accurate detection results and can quantify disease. However, the uneven distribution of the disease and low virus concentrations, especially at the presymptomatic stage, can give false-negative results [17]. In addition, it is time-consuming [18,19] and requires information about the virus' genus or family [20]. Therefore, a rapid but reliable alternative method is needed to detect plant diseases.

One of the methods to effect such detection is by examining the emission of plant volatile organic compounds (VOCs) $[13,21,22]$. Plants produce VOCs as a part of secondary metabolites [23,24], such as hydrocarbon [25], fatty acid derivatives, terpenes, esters, alcohols, aldehydes, ketones [21,26-28], and compounds containing sulfur and nitrogen [29]. They release these VOCs as a form of interaction between themselves and the environment. Moreover, VOCs carry information about the physiological conditions and abiotic and biotic stress they experience [30-32]. Environmental conditions such as temperature, humidity, and water levels cause abiotic stress; organisms such as bacteria, fungi, and viruses that cause plant diseases, lead to biotic stress. VOC emissions from plants that are affected by diseases are different from VOCs that are caused by mechanical damage [26]. Moreover, Jansen et al. [21] argued that the interaction between specific plants and pathogens causes differences in the total emission of the VOC blend. Therefore, it can potentially be used to detect and monitor plant diseases, specifically those caused by viruses.

Gas chromatography-mass spectrometry (GC-MS) can investigate the VOCs released by plants with a disease $[29,33,34]$. This method has been successful in detecting sugar beet powdery mildew [35] and Fusarium coeruleum in potato tubers [36]. Detection of plant diseases by the headspace technique on GC-MS is usually achieved by applying extraction to the plants. Dai et al. used GC-MS to detect strawberry anthrax, and they used metabolome extraction by using methanol/water for the sampling technique [37]. Meanwhile, Cevallos-Cevallos et al. [14] used a combination of liquid extracts and headspace techniques on GC-MS to detect citrus greening disease. However, no research report has investigated the VOCs of chili plants attacked by PYLCV using GC-MS.

Multivariate techniques can make GC-MS results easy to interpret, and several studies have used such techniques to analyze chromatograms. Hu et al. [38] used the hierarchical cluster analysis (HCA) technique to measure the similarity of GC-MS results between Curcumae longae rhizome samples taken from four different origins. Furthermore, to discriminate the sample, partial least squares-discriminant analysis (PLS-DA) and principal component analysis (PCA) were used to find the main chemical markers. As a result, HCA, PLS-DA, and PCA were able to successfully classify Curcumae longae rhizome samples based on their region of origin. Meanwhile, Liu et al. [39] used the partial least squares regression (PLSR) technique to reveal key bioactive components in the traditional Chinese medicine Acori Tatarinowii Rhizoma from its GC-MS results. Outlier elimination and variable selection were applied to improve the performance of the PLSR model. The model was then evaluated by 10 -fold cross-validation and external validation. Based on the PLSR model, eleven chemical components were identified as the main bioactive components with important variables in the projection. The results of the analysis showed that eleven chemical components could be identified as the main bioactive components. A multivariate technique thus showed its ability for in-depth analysis of GC-MS results and revealed the main marker components of the sample.

This preliminary study aimed to examine compounds emitted by PYLCV-infected plants using GC-MS coupled with multivariate analysis technique in actual field conditions. 
Thus, testing was carried out on plants taken from commercial chili fields. PCR tests were performed on symptomatic and asymptomatic plants to confirm the presence or absence of PYLCV. The GC-MS tests were then carried out for the samples. In our method, the sample to be tested with the GC-MS headspace technique was not extracted first but was directly picked from the tree. The samples were then placed into the glass vial for GC-MS testing; hence, the sampling process was faster, easier, and practically applicable. In addition, a shorter sampling process was expected to deliver the actual reading of the VOC emissions from the plants. The main objective of this research was to perform a multivariate analysis technique that could process the GC-MS result by recognizing the infected and uninfected samples. A boxplot analysis was carried out to analyze the variability of VOCs from the plant samples, while the multivariate technique PCA was performed to analyze the total VOC blend of the samples. This was to determine whether the system could distinguish the PYLCV-infected and -undetected samples or not.

\section{Materials and Methods}

\subsection{Samples}

The plant samples used in this research were PYLCV symptomatic and asymptomatic chili plants. There were five plant samples of the same age, which was two months old, investigated in this study. The first sample was a chili plant that had symptoms of PYLCV infection (yellowing and curling leaves) and was taken from a commercial chili plantation in Purworejo, Central Java, Indonesia, in early July 2020 (these samples were referred to as IPJ). The second sample was the same age as IPJ and was taken from the same place with the same plant treatment but showed no symptoms of PYLCV infection (designated by UPJ). GC-MS and PCR testing for the first and second samples were carried out in July 2020. Meanwhile, samples three and four were taken from Purworejo in September 2020, with the third showing symptoms of PYLCV attack and assigned the abbreviation IPS, whereas the fourth did not exhibit symptoms and was designated UPS. The fifth sample (marked as ICS) was a sample of chilies that showed PYLCV disease symptoms but came from a different area, namely Cangkringan, D.I. Yogyakarta. The plants were brought from the plantation to the laboratory using polybags, and their leaves were picked and immediately placed into vials for testing using PCR and GC-MS.

\subsection{Polymerase Chain Reaction}

The samples were tested by polymerase chain reaction (PCR) to confirm the infection of PYLCV. DNA isolation of chili plants was achieved by using a Tiangen genomic DNA extraction kit. Plant leaf samples were weighed at $0.3 \mathrm{~g}$ for isolation. Furthermore, DNA amplification was carried out using the polymerase chain reaction (PCR) method. The primers used were Begomovirus species-specific primers for pepper yellow leaf curl Indonesian virus (PYLCIV) species specificity virus, Pep Uni F (5'-GTG YWG TAY CTT CTG YGG AAY TKG A-3'), and PI Uni R (5'-ACG CCG TAA ACG ATG TTT AYG CG-3') [40]. PCR mix contained Mytaq HS red mix, nuclease-free water (NFW), primer forward, primer reverse, and samples. The PCR mix was placed in a tube, and the PCR process was carried out in a thermocycler machine. In the PCR process, pre-denaturation and denaturation were carried out at a temperature of $95^{\circ} \mathrm{C}$ for $1 \mathrm{~min}$ and $15 \mathrm{~s}$, respectively. Next, annealing was carried out for $15 \mathrm{~s}$ at a temperature of $54{ }^{\circ} \mathrm{C}$. Extension and final extension were then carried out for $10 \mathrm{~s}$ and $5 \mathrm{~min}$ at $72{ }^{\circ} \mathrm{C}$. The PCR process was carried out in 35 cycles.

The results of DNA amplification were visualized using the electrophoresis method, employing $1 \%$ agarose, and Florosafe DNA staining was added for visualizing the DNA. In the process of electrophoresis, agarose gel was placed on an electroporator, Bio-Rad Mini-Sub Cell GT system. The marker used was the $1 \mathrm{k}$ bp marker (base pairs). Electrophoresis was carried out at a power supply voltage of $75 \mathrm{~V}$ for $45 \mathrm{~min}$. Documentation of visualization results was carried out using a UV transilluminator and gel documentation system. The system confirmed the presence or absence of a specific band of PYLCV virus in the samples. 


\subsection{Gas Chromatography-Mass Spectrometry}

The leaves of PYLCV-infected and PYLCV-undetected chili plants were subjected to gas chromatography-mass spectrometry (GC-MS). The GC-MS used in this study was the Thermo Scientific Trace 1310 GC coupled to a Thermo Scientific ISQ LT Single Quadrupole Mass Spectrometer (Thermo Fisher Scientific Inc., San José, CA, USA). The GC-MS employed a static headspace sampling method to extract the VOCs of samples and used the Chromeleon Chromatography Data System (CDS) version 7.2 software (Dionex, Sunnyvale, CA, USA). The column used was HP-5MS UI with a front column length of $30 \mathrm{~m}$ and a front column film thickness of $0.25 \mu \mathrm{m}$. The front inlet split-flow was $20.0 \mathrm{~mL} / \mathrm{min}$, and the purge flow was $3 \mathrm{~mL} / \mathrm{min}$. The gas saver time was $5 \mathrm{~min}$, with a flow of $5 \mathrm{~mL} / \mathrm{min}$. The gas carrier was helium ultra-high purity (UHP), and the column flow rate was $1 \mathrm{~mL} / \mathrm{min}$.

Three leaves of each sample were placed into a glass vial until it reached the equilibrium time of $30 \mathrm{~s}$, and the analytes vaporized on entering the headspace above the sample. The system equilibrated at $60{ }^{\circ} \mathrm{C}$ before the sample was injected into the GC-MS. The injection volume was $1000.00 \mu \mathrm{L}$. In the injection process, the oven was programmed with an initial temperature of $60^{\circ} \mathrm{C}$ and gradually increased at the rate of $5{ }^{\circ} \mathrm{C}$ per minute until it reached $150^{\circ} \mathrm{C}$. The temperature rate was then increased to $10^{\circ} \mathrm{C}$ per minute until it reached $230{ }^{\circ} \mathrm{C}$. The GC-MS sampling process took about $60 \mathrm{~min}$. The identification of compounds was made by mass spectra library matching using the National Institute Standard and Technology (NIST) NIST 14 standard library and references to standard compounds. The GC-MS results were then analyzed by using multivariate analysis.

\subsection{Data Analysis}

The first step in the data analysis was to pre-process the GC-MS results by selecting the compounds for further analysis. The spectra library matching generated three compounds with the highest similarity indexes. The selection of the compounds was based on the literature and the highest similarity index among the three. The acceptance criterion of the similarity index was above 700 (compounds with a similarity lower than 700 were eliminated). Several compounds were identified several times because of their high concentration and tailing. Only one compound was considered for the final list [41]. The GC-MS data were first normalized by considering the summation of all peak areas in the total ion chromatogram (TIC) of one sample as 100\%. Each peak percentage was obtained by dividing its area by the total area of all compounds.

After pre-processing, the variability of the compounds emitted by samples was then analyzed by using a boxplot. This is a statistical method that can visualize the spread of data showing sample differences and the skewness of the dataset. The boxplot displays the first, second (median), and third quartiles. The spread of data is described by the distance between the first and third quartiles and is known as interquartile [42,43]. From the boxplot analysis, we could identify which compounds contributed to the high variability of the dataset.

The total compound blend of the five samples was then classified using PCA analysis to determine whether GC-MS could distinguish PYLCV-infected and PYLVC-undetected from samples taken from the fields. PCA is a multivariate analysis technique that extracts meaningful information from a dataset by reducing data redundancy so that it is easier to interpret. It transforms the data into a new base where the variance of the data is emphasized more [44]. An orthogonal transformation is performed on data variables that are possibly related to each other to obtain principal components (PC) where each PC displays different information. Most of the variance in the original data variables was described by the first few PCs [45]. The score from PCA describes the relationship between samples in the original data, while loading describes the relationship between the variables in the data set [46]. The software used for boxplot and PCA analyses was MATLAB R2020a. 


\section{Results}

The plant samples used in this research were five PYLCV-infected and -undetected plants. Figure 1A shows the chili plantation where the IPJ and UPJ samples were taken, Figure 1B depicts the chili plantation area where ICS was taken, while Figure 1C depicts the IPJ and UPJ. The results of the PCR analysis of all symptomatic plants using the primer pairs PYLCIV Pep Uni F and Pep YLCIV PI Uni R showed the appearance of DNA fragments in plants showing indications of PYLCV infection. Meanwhile, no virus was detected on the asymptomatic plants, confirmed with no DNA bands appearing. Plants that had been tested by PCR were then tested by GC-MS to obtain five chromatograms for three PYLCV-infected plants and two PYLCV-undetected plants.
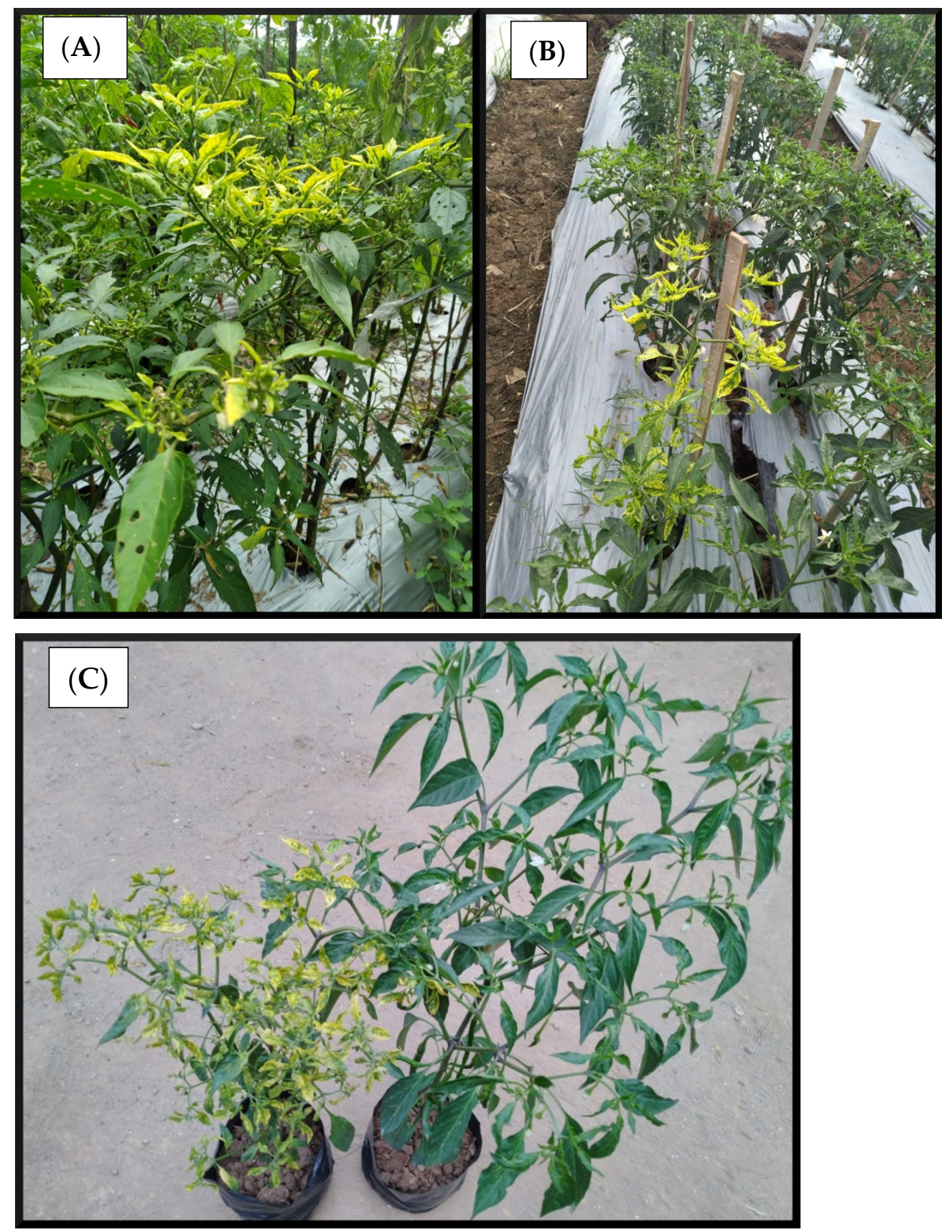

Figure 1. (A) Commercial chili plantation in Purworejo. (B) Commercial chili plantation in Cangkringan. (C) IPJ and UPJ samples. 
The GC-MS data showed 80 compounds from five different samples, including carbon dioxide. The detection of carbon dioxide is possibly due to un-evacuated air inside the sample vial. This compound was then eliminated in further processing. As a result of the pre-processing stage, there were 39 compounds from all five samples (3 PYLCV-infected and 2 PYLVC-undetected). The compounds were VOCs from a variety of functional groups, such as amine (1 compound), other nitrogenous compounds ( 2 compounds), acids (4 compounds), alcohols (6 compounds), aldehydes ( 5 compounds), esters (8 compounds), hydrocarbons (3 compounds), ketones ( 9 compounds), and sulfur compound (1 compound). The details of the compounds with their references are shown in Table 1.

Table 1. Compounds emitted by pepper yellow leaf curl virus (PYLCV)-infected and PYLCV-undetected chili plants determined by gas chromatography-mass spectrometry (GC-MS).

\begin{tabular}{|c|c|c|c|c|c|c|}
\hline \multirow{2}{*}{ Compounds } & \multirow{2}{*}{ Formula } & \multicolumn{5}{|c|}{$\%$ Area } \\
\hline & & IPJ & IPS & ICS & UPJ & UPS \\
\hline \multicolumn{7}{|l|}{ Amine } \\
\hline (2-Aziridinylethyl)amine [47] & C4H10N2 & 54.74 & 30.07 & 6.64 & - & - \\
\hline \multicolumn{7}{|l|}{ Acid } \\
\hline Acetic acid [48] & $\mathrm{C} 2 \mathrm{H} 4 \mathrm{O} 2$ & - & 12.37 & 21.69 & 6.05 & 1.27 \\
\hline Butanedioic acid, 2,3-bis(acetyloxy)-, [R-( $\left.\left.\mathrm{R}^{*}, \mathrm{R}^{*}\right)\right]-[49]$ & $\mathrm{C} 8 \mathrm{H} 10 \mathrm{O} 8$ & - & - & - & - & 2.79 \\
\hline Cyclohexan-1,4,5-triol-3-one-1-carboxylic acid [50] & C7H10O6 & - & - & - & - & 1.96 \\
\hline Hydroxyacetic acid, hydrazide [51] & $\mathrm{C} 2 \mathrm{H} 6 \mathrm{~N} 2 \mathrm{O} 2$ & - & - & - & 3.15 & - \\
\hline \multicolumn{7}{|l|}{ Alcohol } \\
\hline 12-Methyl-E,E-2,13-octadecadien-1-ol [52] & $\mathrm{C} 19 \mathrm{H} 36 \mathrm{O}$ & - & - & - & 0.27 & - \\
\hline 5-Hexen-2-ol [53] & $\mathrm{C} 6 \mathrm{H} 12 \mathrm{O}$ & - & - & - & 6.57 & - \\
\hline $\begin{array}{c}\text { Cyclohexanol, 1-methyl-4-(1-methylethenyl)-, cis- } \\
\text { [54] }\end{array}$ & $\mathrm{C} 10 \mathrm{H} 18 \mathrm{O}$ & - & - & - & - & 0.10 \\
\hline Glycidol [55] & $\mathrm{C} 3 \mathrm{H} 6 \mathrm{O} 2$ & - & 3.29 & 0.18 & - & - \\
\hline Methyl alcohol [56] & $\mathrm{CH} 4 \mathrm{O}$ & - & - & - & 6.26 & - \\
\hline Phenol, 2-ethyl-4,5-dimethyl- [57] & $\mathrm{C} 10 \mathrm{H} 14 \mathrm{O}$ & - & - & - & 0.13 & - \\
\hline \multicolumn{7}{|l|}{ Aldehyde } \\
\hline 1H-Pyrrole-2-carboxaldehyde [58] & $\mathrm{C} 5 \mathrm{H} 5 \mathrm{NO}$ & - & - & 0.24 & - & - \\
\hline Benzaldehyde, 3-benzyloxy-2-fluoro-4-methoxy- [59] & $\mathrm{C} 15 \mathrm{H} 13 \mathrm{FO} 3$ & - & - & - & 0.42 & - \\
\hline Butanal, 2-methyl- [60] & $\mathrm{C} 5 \mathrm{H} 10 \mathrm{O}$ & 0.43 & - & - & - & 3.75 \\
\hline Butanal, 3-methyl- [61] & $\mathrm{C} 5 \mathrm{H} 10 \mathrm{O}$ & 1.14 & - & - & - & 2.40 \\
\hline Propanal, 2-methyl- [62] & $\mathrm{C} 4 \mathrm{H} 8 \mathrm{O}$ & 0.50 & - & - & - & 3.97 \\
\hline \multicolumn{7}{|l|}{ Ester } \\
\hline 10-Octadecenoic acid, methyl ester [63] & С19H36O2 & - & - & - & 2.41 & - \\
\hline $\begin{array}{l}\text { Butanoic acid, 3,7-dimethyl-2,6-octadienyl ester, (E)- } \\
\text { [64] }\end{array}$ & $\mathrm{C} 14 \mathrm{H} 24 \mathrm{O} 2$ & 0.16 & - & - & - & - \\
\hline Cyclopentaneundecanoic acid, methyl ester [65] & $\mathrm{C} 17 \mathrm{H} 32 \mathrm{O} 2$ & - & - & - & 0.44 & - \\
\hline E-2-Octenyl tiglate [66] & $\mathrm{C} 13 \mathrm{H} 22 \mathrm{O} 2$ & - & - & - & 0.53 & - \\
\hline $\begin{array}{c}\text { Formic acid, chloro-, } \\
\text { (3,4,4-trimethyl-1,2-dioxetan-3-yl)methyl ester [67] }\end{array}$ & & - & - & - & - & 6.46 \\
\hline Heptadecanoic acid, 10-methyl-, methyl ester [68] & $\mathrm{C} 19 \mathrm{H} 38 \mathrm{O} 2$ & - & - & - & 0.48 & - \\
\hline Isobutyl tiglate [69] & $\mathrm{C} 9 \mathrm{H} 16 \mathrm{O} 2$ & - & - & - & 0.13 & - \\
\hline Tetradecanoic acid, 12-methyl-, methyl ester, (S)- [70] & $\mathrm{C} 16 \mathrm{H} 32 \mathrm{O} 2$ & - & - & - & 0.47 & - \\
\hline Hydrocarbon & & & & & & \\
\hline 1H-Indene, 2,3-dihydro-1,1,5,6-tetramethyl- [71] & $\mathrm{C} 13 \mathrm{H} 18$ & - & - & - & 0.06 & - \\
\hline 2-Methylbicyclo[4.3.0]non-1(6)-ene [72] & $\mathrm{C} 10 \mathrm{H} 16$ & - & - & 0.09 & - & - \\
\hline Benzene, 2-(1,3-butadienyl)-1,3,5-trimethyl- [73] & $\mathrm{C} 13 \mathrm{H} 16$ & - & - & - & 0.11 & - \\
\hline
\end{tabular}


Table 1. Cont.

\begin{tabular}{|c|c|c|c|c|c|c|}
\hline \multirow{2}{*}{ Compounds } & \multirow{2}{*}{ Formula } & \multicolumn{5}{|c|}{ \%Area } \\
\hline & & IPJ & IPS & ICS & UPJ & UPS \\
\hline \multicolumn{7}{|l|}{ Ketone } \\
\hline 2-Propanone, 1-hydroxy- [74] & $\mathrm{C} 3 \mathrm{H} 6 \mathrm{O} 2$ & - & 0.81 & - & - & 0.46 \\
\hline 2,3-Butanedione [75] & $\mathrm{C} 4 \mathrm{H} 6 \mathrm{O} 2$ & - & - & - & - & 7.79 \\
\hline $\begin{array}{l}\text { 2H-Inden-2-one, } \\
1,4,5,6,7,7 \text { a-hexahydro-7a-methyl-, (S)- [76] }\end{array}$ & $\mathrm{C} 10 \mathrm{H} 14 \mathrm{O}$ & - & - & 0.10 & - & - \\
\hline 6-Methylenebicyclo[3.2.0]hept-3-en-2-one [77] & $\mathrm{C} 8 \mathrm{H} 8 \mathrm{O}$ & - & - & - & - & 0.04 \\
\hline Furaneol [78] & $\mathrm{C} 6 \mathrm{H} 8 \mathrm{O} 3$ & - & - & 0.87 & - & - \\
\hline Megastigmatrienone [79] & $\mathrm{C} 13 \mathrm{H} 18 \mathrm{O}$ & - & - & - & 0.13 & - \\
\hline Maltol [78] & $\mathrm{C} 6 \mathrm{H} 6 \mathrm{O} 3$ & - & - & 0.56 & - & - \\
\hline 2-Piperidinone, N-[4-bromo-n-butyl]- [80] & $\mathrm{C} 9 \mathrm{H} 16 \mathrm{BrNO}$ & - & - & - & 0.30 & - \\
\hline 2-Pyrrolidinone, 1-methyl- [81] & $\mathrm{C} 5 \mathrm{H} 9 \mathrm{NO}$ & - & - & 2.71 & - & - \\
\hline \multicolumn{7}{|l|}{ Nitrogenous compounds } \\
\hline Acetamide, N-(aminoiminomethyl)- [82] & $\mathrm{C} 3 \mathrm{H} 7 \mathrm{~N} 3 \mathrm{O}$ & - & - & - & 14.28 & - \\
\hline o-Aminobenzohydroxamic acid [83] & $\mathrm{C} 7 \mathrm{H} 8 \mathrm{~N} 2 \mathrm{O} 2$ & 0.05 & - & - & - & - \\
\hline \multicolumn{7}{|l|}{ Sulfur Compound } \\
\hline Dimethyl sulfide [84] & $\mathrm{C} 2 \mathrm{H} 6 \mathrm{~S}$ & 1.56 & - & - & - & - \\
\hline
\end{tabular}

The variability of the compounds emitted by the plants constituting the five samples was then investigated by using a boxplot analysis, and the results are shown in Figure 2. The vertical axis of the boxplot shows the 39 compounds, while the horizontal axis depicts the value of the compound percentage area from the GC-MS result. The thick vertical black line shows the median of the samples, the left edge of the grey box indicates the 25th percentiles (Q1), while the 75th percentile (Q3) is represented by the right edge of the box. The interquartile range (Q3-Q1) measures the variability of data [41]. From Figure 2, it can be seen that there are two compounds with the highest variability, namely, (2-aziridinylethyl)amine and acetic acid.

In the next step, PCA analysis was carried out to determine whether the VOC blend emitted by PYLCV-infected and PYLCV-undetected plants could be distinguished or not. The results of GC-MS detection of the five samples that had been normalized and extracted yielded 39 compounds that were then assembled into a $5 \times 39$ matrix to perform PCA. A covariance matrix was generated from the $5 \times 39$ input matrix, which was then manipulated to minimize redundancy and highlight the important characteristics of the data. The eigenvector of the covariance matrix that has been manipulated was then sorted based on the magnitude of the eigenvalue, and the PC values were obtained. Figure 3 is the score plot of the PCA analysis in three dimensions. The total of the PC1, PC2, and PC3 components accounted for $91.32 \%$ of the explained variance, and the analysis of the PC scores showed that there were clear boundary areas that differentiated between PYLCVundetected and -infected plants. Meanwhile, a loading plot analysis to find out which compounds contributed to the PC value is depicted in Figure 4. 


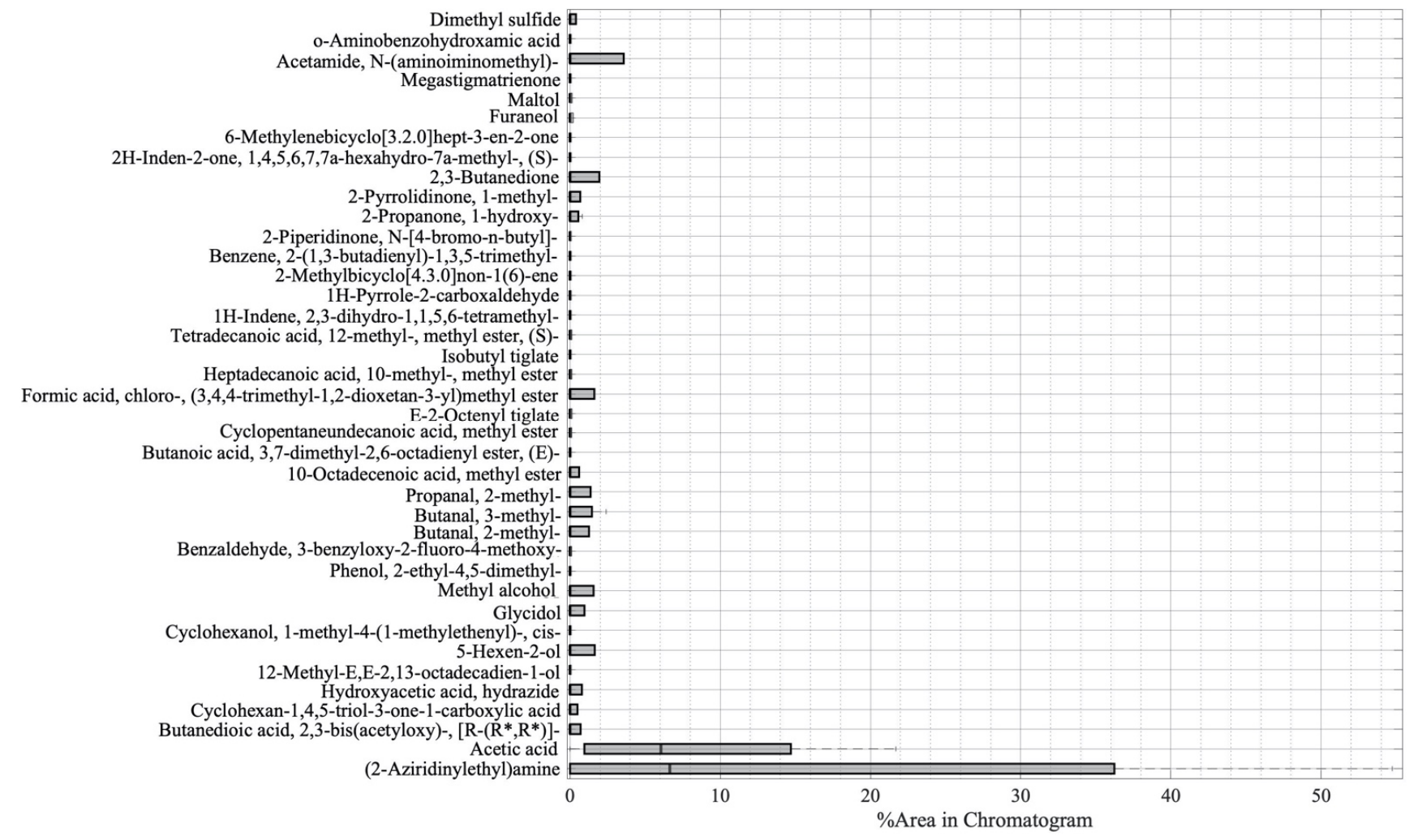

Figure 2. Boxplot analysis of the GC-MS result.

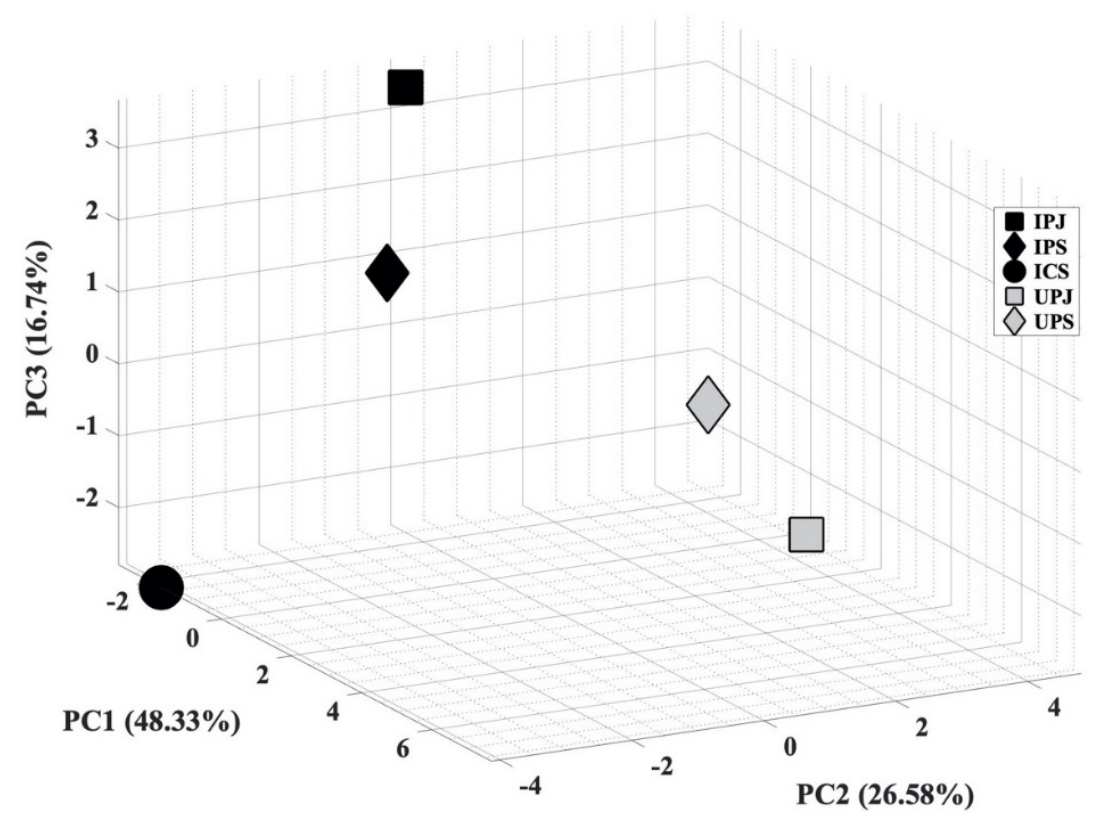

Figure 3. Score plot of principal component analysis (PCA) from GC-MS result. 


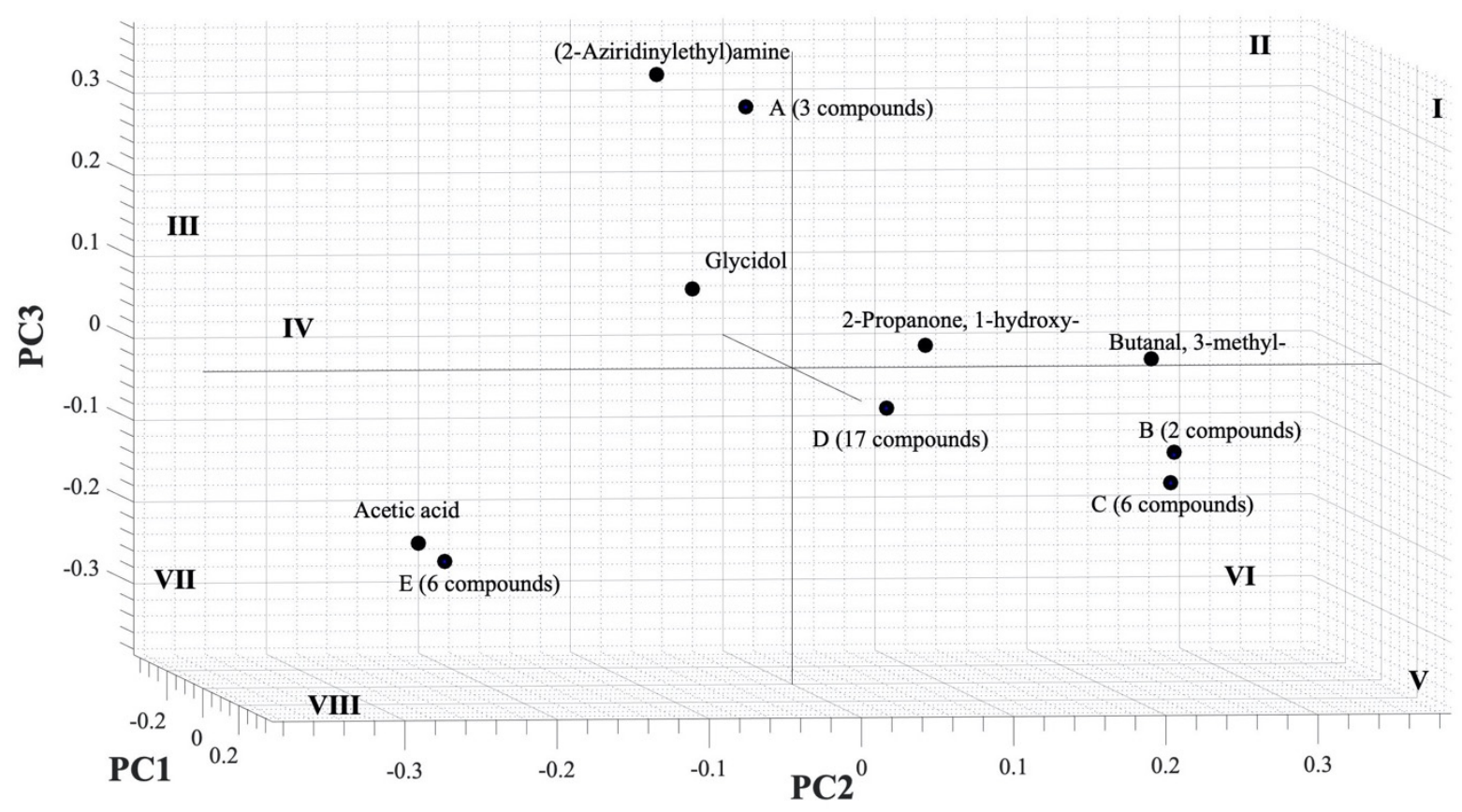

Figure 4. Loading plot of PCA from GC-MS result.

\section{Discussion}

The PCR test confirmed the presence of the virus in the three symptomatic plants and the absence of PYLCV in the two asymptomatic samples. The samples were then subjected to GC-MS, and after the pre-processing, the results showed that there were 39 VOCs from all five samples.

The boxplot analysis in Figure 2 was performed to show the variability of the compounds. From Figure 2, it can be seen that there were two main compounds with a large interquartile, namely, (2-aziridinylethyl)amine and acetic acid. The (2-aziridinylethyl)amine is in the amine functional group, and it is a type of secondary metabolite of plants. Apart from being a part of cell processes such as the division of cells and formation of nucleic acids and proteins, amine has also functioned as a component of chemical and physical defenses in dealing with herbivorous and pathogenic attacks [85]. In the references, (2aziridinylethyl)amine was found on the seed of Persea Americana (Avocado) [86] and on the extract of a plant member of the Araceae family, Colocasia gigantea [47]. However, in those reports, there is no explanation of whether the compounds appear as part of cell processes or because of the stress that was experienced by the plants. In this research, the amine compound (2-aziridinylethyl)amine appeared only in infected plants; hence, we argue that it is a part of the defense from pathogenic attacks. However, further investigation needs to be undertaken to prove that (2-aziridinylethyl)amine can be used as a potential biomarker for PYLCV detection. On the other hand, acetic acid was the compound with the second-highest variability and appeared in all samples, except for IPJ. Plants release acetic acid as part of adaptation to biotic and abiotic stress [30], but, as demonstrated by IPJ, it may not always be emitted. This inconsistency is probably due to the differences in the environmental conditions, causing differences in the plants' biotic stress.

Compounds, such as acetamide, N-(aminoiminomethyl)-, 2,3-butanedione, 5-hexen-2ol, formic acid, chloro-, (3,4,4-trimethyl-1,2-dioxetan-3-yl)methyl ester, methyl alcohol, propanal, 2-methyl-, butanal, 3-methyl-, had a variability between 1 to 5 of the percentage area. Other compounds only made contributions below one of the percentage areas. Among these compounds, there were antimicrobial and antiparasitic compounds emitted by the PYLCV-undetected pants. Cyclopentaneundecanoic acid, methyl ester (antimicrobial [65,87]), 12-methyl-E,E-2,13-octadecadien-1-ol (anti-microbial and antifungal agent $[87,88]$ ), and 2-piperidinone, N-[4-bromo-n-butyl]- (antimicrobial and an- 
tioxidant [80]) were emitted by UPJ, while 6-methylenebicyclo [3.2.0] hept-3-en-2-one (antiparasitic $[77,89]$ ) was emitted by UPS. However, the compounds were not found in the PYLCV-infected plants. The emission of these compounds was probably a form of defense of the plants.

Several compounds were found in more than one sample. Glycidol and 2-propanone, 1-hydroxy- were found in the infected plants IPS and UPS. Butanal, 2-methyl- and propanal, 2-methyl- were emitted by IPJ and virus-undetected UPS. The compounds emitted by plants from the same area, which is Purworejo.

The boxplot analysis was only carried out to investigate the variability of compounds. Furthermore, the PCA analysis was performed to ascertain whether the total blend of compounds in the GC-MS results from PYLCV-infected and -undetected plants was distinguishable or not. As shown in Figure 3, there is a clear separation between PYLCV-infected leaf samples and those not detected with PYLCV. The separator is a diagonal mirror plane that forms a $45^{\circ}$ angle to the PC1 and the PC2 axes. PYLCV-undetected plants were seen on the positive axis of PC2, while the three infected samples were on the negative axis of PC2. This suggests that PCA can differentiate between PYLCV-infected and PYLCV-undetected plants.

A loading plot analysis was also carried out to find out which compounds contributed to the PC value and is depicted in Figure 4. The (2-aziridinylethyl)amine had a high contribution to PC 3 and negative PC2, and, as seen in Table 1, the compound was only found in infected samples (IPJ, IPS, and ICS) and was emitted in large numbers by IPJ and IPS; therefore, it was also located in the quadrant III, the same as IPJ and IPS in Figure 3. Meanwhile, acetic acid contributed to negative PC2 and lay in the same quadrant (VII) as the PYLCV-infected plants. Likewise, other compounds detected in more than one sample appear to have contributed to the PC value. Glycidol contributed to negative PC1 and was in the same quadrant as the PYLCV-infected plants in the score plot in Figure 3, and from Table 1, it is known that glycidol was only found in IPS and ICS.

The compounds found in only one sample also contributed to the PC value. Six compounds in point $\mathrm{E}$ (1H-pyrrole-2-carboxaldehyde, 2-methylbicyclo[4.3.0]non-1(6)-ene, 2-pyrrolidinone, 1-methyl-, 2H-inden-2-one, 1,4,5,6,7,7a-hexahydro-7a-methyl-, (S)-, furaneol) were only detected in ICS and located in the same quadrant (VII) as ICS in Figure 3. Meanwhile, three compounds in point A, butanoic acid, 3,7-dimethyl-2,6-octadienyl ester, (E)-, dimethyl sulfide, and o-aminobenzohydroxamic acid, were emitted by IPJ and located in quadrant III. Furthermore, six compounds in point C (2,3-butanedione, 6methylenebicyclo[3.2.0]hept-3-en-2-one, butanedioic acid, 2,3-bis(acetyloxy)-, [R-( $\left.\left.R^{*}, R^{*}\right)\right]$-, cyclohexan-1,4,5-triol-3-one-1-carboxylic acid, cyclohexanol, 1-methyl-4-(1-methylethenyl)-, cis-, formic acid, chloro-, (3,4,4-trimethyl-1,2-dioxetan-3-yl)methyl ester) were found only on UPS and were in quadrant V. Meanwhile, compounds emitted by UPJ such as 10octadecenoic acid, methyl ester, 12-methyl-E,E-2,13-octadecadien-1-ol, 1H-indene, 2,3dihydro-1,1,5,6-tetramethyl-, 2-piperidinone, N-[4-bromo-n-butyl]-, 5-hexen-2-ol, acetamide, $\mathrm{N}$-(aminoiminomethyl)-, benzaldehyde, 3-benzyloxy-2-fluoro-4-methoxy-, benzene, 2-(1,3butadienyl)-1,3,5-trimethyl-, cyclopentaneundecanoic acid, methyl ester, E-2-octenyl tiglate, heptadecanoic acid, 10-methyl-, methyl ester, hydroxyacetic acid, hydrazide, isobutyl tiglate, megastigmatrienone, methyl alcohol, phenol, 2-ethyl-4,5-dimethyl- and tetradecanoic acid, 12-methyl-, methyl ester, (S)- (17 compounds in point $\mathrm{D}$ ) were in quadrant $\mathrm{V}$. Analysis of the PC scores showed that there were clear boundary areas that differentiated between PYLCV-detected and -infected plants.

\section{Conclusions}

A new method to distinguish PYLCV-infected from PYLCV-undetected plants has been developed. This method is based on GC-MS analysis and its interpretation using multivariate analysis techniques. The boxplot analysis showed that two main compounds contribute to the largest variability of the VOCs emitted by the two kinds of samples: (2-aziridinylethyl)amine and acetic acid. Acetic acid appeared inconsistently between 
samples because of the effects of the weather and environmental conditions. Meanwhile, (2-aziridinylethyl)amine is only found in infected plants. However, further research needs to be done to ensure it is a potential biomarker of PYLCV-infected plants.

PCA was then performed to see whether GC-MS can distinguish the compounds' total blend of PYLCV-infected and PYLCV-undetected chili plants. The results showed that PCA delivered a clear separation between the PYLCV-infected and -undetected chili plants, with the total variance of PC1, PC2, and PC3 reaching 91.32\%. The loading plot analysis showed that (2-aziridinylethyl)amine and acetic acid made high contributions to the component score of PC2; therefore, the samples were separable on the PC2 axis. This demonstrates that GC-MS can be used as a highly effective and reliable method to detect plant disease.

Author Contributions: Conceptualization, D.K.A., D.D.I. and M.S.L.; methodology, D.K.A., I.S.M., N.A.A., C.W.P., D.D.I. and M.S.L.; software, D.K.A.; validation, I.S.M., C.W.P. and K.T.; formal analysis, D.K.A. and M.S.L.; investigation, I.S.M., N.A.A. and C.W.P.; resources, I.S.M., N.A.A. and K.T.; data curation, D.K.A., C.W.P., D.D.I. and M.S.L.; writing-original draft preparation, D.K.A.; writing-review and editing, I.S.M., N.A.A., C.W.P., K.T., D.D.I. and M.S.L.; visualization, D.K.A.; supervision, D.D.I. and M.S.L.; project administration, D.K.A.; funding acquisition, D.K.A. All authors have read and agreed to the published version of the manuscript.

Funding: This research was funded by the Indonesia Endowment Fund for Education (LPDP), Ministry of Finance, Republic of Indonesia, grant number S-2507/LPDP.4/2019.

Conflicts of Interest: The authors declare no conflict of interest.

\section{References}

1. Kim, I.-K.; El-Aty, A.M.A.; Shin, H.-C.; Lee, H.B.; Shim, J.-H.; Kim, I.-S. Analysis of volatile compounds in fresh healthy and diseased peppers (Capsicum annuum L.) using solvent free solid injection coupled with gas chromatography-flame ionization detector and confirmation with mass spectrometry. J. Pharm. Biomed. Anal. 2007, 45, 487-494. [CrossRef] [PubMed]

2. Saleh, B.K.; Omer, A.; Teweldemedhin, B. Medicinal uses and health benefits of chili pepper (Capsicum spp.): A review. MOJ Food Process. Technol. 2018, 6, 1. [CrossRef]

3. Suryani, R. Outlook Cabai Komoditas Pertanian Sub Sektor Hortikultura; Pusat Data dan Sistem Informasi Pertanian Sekretariat Jenderal Kementerian Pertanian: Jakarta, Indonesia, 2019.

4. De Barro, P.J.; Hidayat, S.H.; Frohlich, D.; Subandiyah, S.; Ueda, S. A virus and its vector, pepper yellow leaf curl virus and Bemisia tabaci, two new invaders of Indonesia. Biol. Invasions 2007, 10, 411-433. [CrossRef]

5. Trisno, J.; Habazar, T.; Manti, I.; Jamsari, J.; Hidayat, S.H. Detection and Sequence Diversity of Begomovirus Associated with Yellow Leaf Curl Disease of Pepper (Capsicum annuum) in West Sumatra, Indonesia. Microbiol. Indones. 2009, 3, 56-61. [CrossRef]

6. Luas Komulatif Serangan Opt Cabai 2018 \& 2019. Direktorat Perlindungan Hortikultura. 2020. Available online: http:/ / ditlin. hortikultura.pertanian.go.id/index.php/page/index/Luas-Komulatif-Serangan-OPT-Cabai-2018-2019 (accessed on 6 September 2020).

7. Ganefianti, D.W.; Hidayat, S.H.; Syukur, M. Susceptible Phase of Chili Pepper Due to Yellow Leaf Curl Begomovirus Infection. Int. J. Adv. Sci. Eng. Inf. Technol. 2017, 7, 594. [CrossRef]

8. Windarningsih, M. Identification of virus causing the yellow leaf curl diseases on chili pepper in Lombok Island by PCR-RFLP technique. AIP Conf. Proc. 2019, 2199, 040010. [CrossRef]

9. Rai, V.P.; Kumar, R.; Singh, S.P.; Kumar, S.; Kumar, S.; Singh, M.; Rai, M. Monogenic recessive resistance to Pepper leaf curl virus in an interspecific cross of Capsicum. Sci. Hortic. 2014, 172, 34-38. [CrossRef]

10. Kesumawati, E.; Okabe, S.; Homma, K.; Fujiwara, I.; Zakaria, S.; Kanzaki, S.; Koeda, S. Pepper yellow leaf curl Aceh virus: A novel bipartite begomovirus isolated from chili pepper, tomato, and tobacco plants in Indonesia. Arch. Virol. 2019, 164, 2379-2383. [CrossRef]

11. Sulandari, S.; Hidayat, S.H.; Suseno, R.; Harjosudarmo, J.; Sosromarsono, S. Transmission of Pepper Yellow Leaf Curl Virus by the Insect Vector Bemisia Tabaci Genn. (Hemiptera: Aleyrodidae). Int. Soc. Southeast Asian Agric. Sci. 2007, 13, $10-17$.

12. Selangga, D.G.W.; Hidayat, S.H.; Susila, A.D.; Wiyono, S. The Effect of Silica (SiO2) to the Severity of Yellow Leaf Curl Disease on Chili Pepper. J. Perlindungan Tanam. Indones. 2019, 23, 54-60. [CrossRef]

13. Martinelli, F.; Scalenghe, R.; Davino, S.; Panno, S.; Scuderi, G.; Ruisi, P.; Villa, P.; Stroppiana, D.; Boschetti, M.; Goulart, R.L.; et al. Advanced methods of plant disease detection. A review. Agron. Sustain. Dev. 2015, 35, 1-25. [CrossRef]

14. Cevallos-Cevallos, J.M.; García-Torres, R.; Etxeberria, E.; Reyes-De-Corcuera, J.I. GC-MS Analysis of Headspace and Liquid Extracts for Metabolomic Differentiation of Citrus Huanglongbing and Zinc Deficiency in Leaves of 'Valencia' Sweet Orange from Commercial Groves. Phytochem. Anal. 2010, 22, 236-246. [CrossRef]

15. Rubio, L.; Galipienso, L.; Ferriol, I. Detection of Plant Viruses and Disease Management: Relevance of Genetic Diversity and Evolution. Front. Plant Sci. 2020, 11, 1092. [CrossRef] [PubMed] 
16. Kumlachew, A. Detection of diseases, identification and diversity of viruses: A Review. J. Biol. Agric. Healthc. 2015, 5, 204-214.

17. Li, Z.; Paul, R.; Tis, T.B.; Saville, A.C.; Hansel, J.C.; Yu, T.; Ristaino, J.; Wei, Q. Non-invasive plant disease diagnostics enabled by smartphone-based fingerprinting of leaf volatiles. Nat. Plants 2019, 5, 856-866. [CrossRef]

18. Qiu, R.; Qu, D.; Hardy, G.E.S.J.; Trengove, R.; Agarwal, M.; Ren, Y. Headspace solid-phase microextraction and gas chromatography-mass spectrometry for analysis of VOCs produced by Phytophthora cinnamomi. Plant Dis. 2014, 98, 1099-1105 [CrossRef] [PubMed]

19. Hariharan, G.; Prasannath, K. Recent Advances in Molecular Diagnostics of Fungal Plant Pathogens: A Mini Review. Front. Cell. Infect. Microbiol. 2021, 10,1-14. [CrossRef]

20. Blouin, A.G.; Greenwood, D.R.; Chavan, R.R.; Pearson, M.N.; Clover, G.R.; MacDiarmid, R.M.; Cohen, D. A generic method to identify plant viruses by high-resolution tandem mass spectrometry of their coat proteins. J. Virol. Methods 2010, 163, 49-56. [CrossRef]

21. Jansen, R.M.C.; Wildt, J.; Kappers, I.F.; Bouwmeester, H.J.; Hofstee, J.W.; Van Henten, E.J. Detection of diseased plants by analysis of volatile organic compound emission. Annu. Rev. Phytopathol. 2011, 49, 157-174. [CrossRef] [PubMed]

22. Nicolì, F.; Negro, C.; Nutricati, E.; Vergine, M.; Aprile, A.; Sabella, E.; Damiano, G.; De Bellis, L.; Luvisi, A. Accumulation of Azelaic Acid in Xylella fastidiosa-Infected Olive Trees: A Mobile Metabolite for Health Screening. Phytopathology 2019, 109, 318-325. [CrossRef]

23. Picazo-Aragonés, J.; Terrab, A.; Balao, F. Plant Volatile Organic Compounds Evolution: Transcriptional Regulation, Epigenetics and Polyploidy. Int. J. Mol. Sci. 2020, 21, 8956. [CrossRef]

24. Sekine, T.; Appiah, K.S.; Azizi, M.; Fujii, Y. Plant Growth Inhibitory Activities and Volatile Active Compounds of 53 Spices and Herbs. Plants 2020, 9, 264. [CrossRef]

25. Sharkey, T.D.; Wiberley, A.E.; Donohue, A.R. Isoprene emission from plants: Why and how. Ann. Bot. 2008, 101, 5-18. [CrossRef] [PubMed]

26. Dorokhov, Y.L.; Komarova, T.V.; Sheshukova, E. Volatile organic compounds and plant virus-host interaction. In Plant Virus-Host Interaction; Academic Press: Cambridge, MA, USA, 2014; pp. 241-262.

27. Dudareva, N.; Negre, F.; Nagegowda, D.; Orlova, I. Plant Volatiles: Recent Advances and Future Perspectives. Crit. Rev. Plant Sci. 2006, 25, 417-440. [CrossRef]

28. Cape, J. Effects of airborne volatile organic compounds on plants. Environ. Pollut. 2003, 122, 145-157. [CrossRef]

29. Tholl, D.; Hossain, O.; Weinhold, A.; Röse, U.S.R.; Wei, Q. Trends and applications in plant volatile sampling and analysis. Plant J. 2021, 106, 314-325. [CrossRef] [PubMed]

30. Seco, R.; Penuelas, J.; Filella, I. Short-chain oxygenated VOCs: Emission and uptake by plants and atmospheric sources, sinks, and concentrations. Atmos. Environ. 2007, 41, 2477-2499. [CrossRef]

31. Zhou, B.; Wang, J. Discrimination of different types damage of rice plants by electronic nose. Biosyst. Eng. 2011, 109, 250-257. [CrossRef]

32. Montejano-Ramírez, V.; García-Pineda, E.; Valencia-Cantero, E. Bacterial Compound N,N-Dimethylhexadecylamine Modulates Expression of Iron Deficiency and Defense Response Genes in Medicago truncatula Independently of the Jasmonic Acid Pathway. Plants 2020, 9, 624. [CrossRef]

33. Simko, I.; Jimenez-Berni, J.A.; Sirault, X.R.R. Phenomic Approaches and Tools for Phytopathologists. Phytopathology 2017, 107, 6-17. [CrossRef]

34. Bos, L.D.J.; Sterk, P.J.; Schultz, M.J. Volatile Metabolites of Pathogens: A Systematic Review. PLoS Pathog. 2013,9 , e1003311. [CrossRef]

35. Eid, K.; El-Sayed, A.-N.; Shoala, T. Gas Chromatography-Mass Spectrometry (GC-MS) Analysis of Sugar Beet Leaf Extracts in Response to Exogenous Application of Resistance Inducers to Manage Sugar Beet Powdery Mildew. Egypt. J. Phytopathol. 2018, 46, 257-277. [CrossRef]

36. De Lacy Costello,, B.P.J.; Evans, P.; Ewen, R.J.; Gunson, H.E.; Jones, P.R.H.; Ratcliffe, N.M.; Spencer-Phillips, P.T.N. Gas chromatography-mass spectrometry analyses of volatile organic compounds from potato tubers inoculated with Phytophthora infestans or Fusarium coeruleum. Plant Pathol. 2001, 50, 489-496. [CrossRef]

37. Dai, T.; Chang, X.; Hu, Z.; Liang, L.; Sun, M.; Liu, P.; Liu, X. Untargeted Metabolomics Based on GC-MS and Chemometrics: A New Tool for the Early Diagnosis of Strawberry Anthracnose Caused by Colletotrichum theobromicola. Plant Dis. 2019, 103, 2541-2547. [CrossRef]

38. Hu, Y.; Kong, W.; Yang, X.; Xie, L.; Wen, J.; Yang, M. GC-MS combined with chemometric techniques for the quality control and original discrimination of Curcumae longae rhizome: Analysis of essential oils. J. Sep. Sci. 2014, 37, 404-411. [CrossRef]

39. Liu, W.; Zhang, B.; Xin, Z.; Ren, D.; Yi, L. GC-MS Fingerprinting Combined with Chemometric Methods Reveals Key Bioactive Components in Acori Tatarinowii Rhizoma. Int. J. Mol. Sci. 2017, 18, 1342. [CrossRef]

40. Kesumawati, E.; Okabe, S.; Khalil, M.; Alfan, G.; Bahagia, P.; Pohan, N.; Zakaria, S.; Koeda, S. Molecular Characterization of Begomoviruses Associated with Yellow Leaf Curl Disease in Solanaceae and Cucurbitaceae Crops from Northern Sumatra, Indonesia. Hortic. J. 2020, 89, 410-416. [CrossRef]

41. Mills, T.C. Presenting and Summarising Data. Anal. Econ. Data 2014, 6, 66-71. [CrossRef]

42. Krzywinski, M.; Altman, N. Visualizing samples with box plots. Nat. Methods 2014, 11, 119-120. [CrossRef] [PubMed] 
43. Marmolejo-Ramos, F.; Tian, T.S. The shifting boxplot. A boxplot based on essential summary statistics around the mean. Int. J. Psychol. Res. 2010, 3, 37-45. [CrossRef]

44. Shlens, J. A tutorial on principal component analysis. arXiv 2014, arXiv:1404.1100, preprint.

45. Lajis, N.; Maulidiani, M.; Abas, F.; Ismail, I. Metabolomics Approach in Pharmacognosy. In Pharmacognosy: Fundamentals, Applications and Strategy; Elsevier Inc.: Amsterdam, The Netherlands, 2017.

46. Reaser, B.C.; Watson, N.E.; Prebihalo, S.E.; Pinkerton, D.K.; Skogerboe, K.J.; Synovec, R.E. Management and interpretation of capillary chromatography-mass spectrometry data. In Hyphenations of Capillary Chromatography with Mass Spectrometry; Elsevier BV: Amsterdam, The Netherlands, 2020; pp. 449-480.

47. Pornprasertpol, A.; Sereemaspun, A.; Sooklert, K.; Satirapipatkul, C.; Sukrong, S. Anticancer activity of selected Colocasia gigantia fractions. J. Med. Assoc. Thail. 2015, 98, S98-S106.

48. Aguirre, J.L.; Baena, J.; Martín, M.T.; González, S.; Manjón, J.L.; Peinado, M. Herbicidal effects of wood vinegar on nitrophilous plant communities. Food Energy Secur. 2020, 9, 1-18. [CrossRef]

49. Kaur, R.; Malik, C.P. Cissus quadrangularis L.-Its botany, chemistry and medicinal importance: A review. Int. J. Pharm. Clin. Res. 2014, 6, 27-35.

50. Bhattacharyya, R.; Medhi, K.K.; Borkataki, S. Phytochemical analysis of Drymaria cordata (L.) willd. ex schult. (whole plant) used by tea tribes of erstwhile Nagaon district of Assam, India. Int. J. Pharm. Sci. Res. 2019, 10, 4264-4269. [CrossRef]

51. Al-Mussawi, Z.K.; Al-Hussani, I.M. Phytochemical study of Calendula officinalis plant by used GC-MS and FTIR techniques. Plant Arch. 2019, 19, 845-851.

52. Sasikala, K.; Chandra Mohan, S. Total phenolic, Flavanoid contents and GC-MS analysis of canthium coromandelicum leaves extract. Int. J. Pharm. Pharm. Sci. 2014, 6, 379-381.

53. Lee, K.-G.; Shibamoto, T. Antioxidant activities of volatile components isolated fromEucalyptus species. J. Sci. Food Agric. 2001, 81, 1573-1579. [CrossRef]

54. Samarasinghe, D.K.; Virginia, W. Morphological, Genetic and Biochemical Characterization of The Anti-Malarial Herb, Artemisia Annua Germplasm Collection at West Virginia, Division of Plant and Soil Sciences; Davis College of Agriculture, Natural Resources and Design: Morgantown, WV, USA, 2018.

55. Jadhav, V.; Kalase, V.; Patil, P. GC-MS analysis of bioactive compounds in methanolic extract of Holigarna grahamii (wight) Kurz. Int. J. Herb. Med. 2014, 35, 35-39.

56. Ōnishi, I.; Tomita, H.; Fukuzumi, T. Studies on the essential oils of tobacco leaves: Part XV. The neutral fraction. J. Agric. Chem. Soc. Jpn. 2014, 21, 239-242. [CrossRef]

57. Semeniuc, C.A.; Socaciu, M.-I.; Socaci, S.A.; Mureșan, V.; Nagy, M.; Rotar, A.M. Chemometric Comparison and Classification of Some Essential Oils Extracted from Plants Belonging to Apiaceae and Lamiaceae Families Based on Their Chemical Composition and Biological Activities. Molecules 2018, 23, 2261. [CrossRef]

58. Caporaso, N.; Whitworth, M.B.; Cui, C.; Fisk, I.D. Variability of single bean coffee volatile compounds of Arabica and robusta roasted coffees analysed by SPME-GC-MS. Food Res. Int. 2018, 108, 628-640. [CrossRef] [PubMed]

59. Ai, Z.; Zhang, B.; Chen, Y.; Yu, Z.; Chen, H.; Ni, D. Impact of light irradiation on black tea quality during withering. J. Food Sci. Technol. 2017, 54, 1212-1227. [CrossRef]

60. Cai, L.; Koziel, J.A.; O’Neal, M.E. Studying Plant-Insect Interactions with Solid Phase Microextraction: Screening for Airborne Volatile Emissions Response of Soybeans to the Soybean Aphid, Aphis glycines Matsumura (Hemiptera: Aphididae). Chromatography 2015, 2, 265-276. [CrossRef]

61. Widyawati, P.S.; Wijaya, C.H.; Hardjosworo, P.S.; Sajuthi, D. Volatile Compounds of Pluchea indica Less and Ocimum basillicum Linn Essential Oiland Potency as Antioxidant. Hayati J. Biosci. 2013, 20, 117-126. [CrossRef]

62. Ko, A.-Y.; Rahman, M.; El-Aty, A.A.; Jang, J.; Choi, J.-H.; Mamun, M.; Shim, J.-H. Identification of volatile organic compounds generated from healthy and infected powdered chili using solvent-free solid injection coupled with GC/MS: Application to adulteration. Food Chem. 2014, 156, 326-332. [CrossRef] [PubMed]

63. Banaras, S.; Javaid, A.; Shoaib, A.; Ahmed, E. Antifungal activity of cirsium arvense extracts against phytopathogenic fungus macrophomina phaseolina. Planta Daninha 2017, 35, e017162738. [CrossRef]

64. Al-wassouf, G. Chemical composition of the essential oil of Lavandula angustifolia from Syria. Chem. Mater. Res. 2018, 10, 1.

65. Chenniappan, J.; Sankaranarayanan, A.; Arjunan, S. Evaluation of Antimicrobial Activity of Cissus quadrangularis L. stem extracts against Avian Pathogens and Determination of its Bioactive Constituents using GC-MS. J. Sci. Res. 2020, 64, 90-96. [CrossRef]

66. Madi, Y.F.; Choucry, M.A.; Meselhy, M.R.; El-Kashoury, E.S.A. Essential oil of Cymbopogon citratus cultivated in Egypt: Seasonal variation in chemical composition and anticholinesterase activity. Nat. Prod. Res. 2020, 1-7. [CrossRef]

67. Dong, S.; Bi, H.; Zheng, D.; Li, Y.; Zhao, Y.; Peng, W. Bioactive constituents and biodrugs from Euphorbia tirucalli stene. J. Environ. Biol. 2019, 40, 524-535. [CrossRef]

68. Odion, E.E.; Ogboru, R.O.; Ighene, M.O. Identification of Compounds in Elaeis guineensis Fruits using GC-MS. Dhaka Univ. J. Pharm. Sci. 2020, 19, 153-159. [CrossRef]

69. Khan, M.; Khan, M.; Abdullah, M.M.; Al-Wahaibi, L.H.; Alkhathlan, H.Z. Characterization of secondary metabolites of leaf and stem essential oils of Achillea fragrantissima from central region of Saudi Arabia. Arab. J. Chem. 2020, 13, 5254-5261. [CrossRef] 
70. Rahman, J.; Tareq, A.; Hossain, M.; Sakib, S.; Islam, M.; Ali, H.; Uddin, A.; Hoque, M.; Nasrin, M.; Emran, T.; et al. Biological Evaluation, DFT Calculations and Molecular Docking Studies on the Antidepressant and Cytotoxicity Activities of Cycas pectinata Buch. -Ham. Compounds. Pharmaceuticals 2020, 13, 232. [CrossRef]

71. Sheibani, E.; Duncan, S.E.; Kuhn, D.; Dietrich, A.; Newkirk, J.J.; O’Keefe, S.F. Changes in flavor volatile composition of oolong tea after panning during tea processing. Food Sci. Nutr. 2016, 4, 456-468. [CrossRef]

72. Jayakumar, M.; Ramachandran, M.; Krishnaveni, T.; Nattudurai, G. Toxicity and biochemical effects of essential oils of Anethum graveolens L. and Melaleuca cajuputi Powell against Rhyzopertha dominica (F.) (Coleoptera: Bostrichidae). Int. J. Trop. Insect Sci. 2021, 41, 945-951. [CrossRef]

73. Hariharan, A.; Hussain, M.I.M.; Kumpati, P.K.; Tajuddin, N.B.; Mathew, S.; Qadri, I. Chemical composition of the hexane extract of leaves of Azima tetracantha (LAM). Asian J. Plant Sci. Res. 2015, 5, 1-5.

74. Teamkao, P.; Thiravetyan, P. Phytoremediation of Mono-, Di-, and Triethylene Glycol by Echinodorus cordifolius L. Griseb. Int. J. Phytoremediat. 2014, 17, 93-100. [CrossRef]

75. Yang, Y.; Chen, S.; Peng, L.; Liu, X.; Kaushal, R.; Yuan, F.; Singh, S.K.; He, D.; Lv, S.; Vílchez, J.I.; et al. Latent defense response to non-pathogenic microbial factors impairs plant-rhizobacteria mutualism. bioRxiv 2020. [CrossRef]

76. Palariya, D.; Singh, A.; Dhami, A.; Kumar, R.; Pant, A.K.; Prakash, O. Phytochemical analysis and screening of antioxidant, antibacterial and anti- inflammatory activity of essential oil of Premna mucronata Roxb. Leaves. Trends Phytochem. Res. 2019, 3, 275-286.

77. Hussein, H.J.; Mohammed, Y.H.; Imad, H.H. Study of chemical composition of Foeniculum vulgare using Fourier transform infrared spectrophotometer and gas chromatography-Mass spectrometry. J. Pharmacogn. Phytother. 2016, 8, 60-89. [CrossRef]

78. Schwab, W.; Davidovich-Rikanati, R.; Lewinsohn, E. Biosynthesis of plant-derived flavor compounds. Plant J. 2008, 54, 712-732. [CrossRef]

79. Bai, S.; Seasotiya, L.; Malik, A.; Bharti, P.; Dalal, S. GC-MS analysis of chloroform extract of Acacia nilotica L. Leaves. J. Pharmacogn. Phytochem. 2014, 2, 79-82.

80. Al-Bahadily, D.; Shari, F.; Najm, M.; Al-Salman, H. Antimicrobial Activity of the Compound 2-Piperidinone, N-[4-Bromo-n-butyl]Extracted from Pomegranate Peels. Asian J. Pharm. 2019, 13, 46-53. [CrossRef]

81. Ghosh, S.; Derle, A.; Ahire, M.; More, P.; Jagtap, S.; Phadatare, S.D.; Patil, A.B.; Jabgunde, A.M.; Sharma, G.K.; Shinde, V.S.; et al. Phytochemical Analysis and Free Radical Scavenging Activity of Medicinal Plants Gnidia glauca and Dioscorea bulbifera. PLoS ONE 2013, 8, e82529. [CrossRef]

82. YangLi, Y.; Chen, X.; Ashraf, M.A.; Liu, Z.; Bi, H.; Zheng, D.; Zhao, Y.; Peng, W. Molecules and functions of Aesculus chinensis Bunge Bark volatiles. Emir. J. Food Agric. 2018, 30, 809-819.

83. Kurian, S.; Joseph, L.; Josekumar, V.S. Phytochemical evaluation, GC-MS analysis and antimicrobial activity of the leaves petiole of Artocarpus heterophyllus Lam. Asian J. Pharm. Pharmacol. 2018, 4, 280-287. [CrossRef]

84. Giacomuzzi, V.; Cappellin, L.; Nones, S.; Khomenko, I.; Biasioli, F.; Knight, A.L.; Angeli, S. Diel rhythms in the volatile emission of apple and grape foliage. Phytochemistry 2017, 138, 104-115. [CrossRef]

85. Bouchereau, A.; Gueno, P.; Larher, F. Review: Analysis of amines in plant materials Alain. J. Chromatogr. B 2000, 747, 49-67. [CrossRef]

86. Maduka, T.O.; Chiyere, I.; Georgina, K. Physicochemical Characterization and Assessment of Bioactive Chemical Compounds of Persea Americana (Avocado) Seed. J. Nat. Ayurvedic Med. 2020, 4, 1-11. [CrossRef]

87. Lakshmi, C.N.D.M.; Prabhakara, J.P.R.; Saritha, K.; Raju, B.D.P.; Sushma, N.J. Phytoconstituents Profile of Clitoria Ternatea by Gc-Ms and Its Age-Related Anticholinergic Activity Against Aluminum and Restraint Stress. Int. Res. J. Pharm. 2018, 9, 38-44. [CrossRef]

88. Hayat, M.M.; Uzair, M. Biological potential and GC-MS analysis of phytochemicals of Farsetia hamiltonii (Royle). Biomed. Res. 2019, 30, 609-616. [CrossRef]

89. Ali, A.; Javaid, A.; Shoaib, A. Gc-Ms Analysis and Antifungal Activity of Methanolic Root Extract of Chenopodium album against Sclerotium rolfsii. Planta Daninha 2017, 35. [CrossRef] 